Article

\title{
Antioxidant Properties and the Formation of Iron Coordination Complexes of 8-Hydroxyquinoline
}

\author{
Vladimir Chobot ${ }^{1, *} \mathbb{0}$, Franz Hadacek ${ }^{2}$, Gert Bachmann ${ }^{1}{ }^{1}$, Wolfram Weckwerth ${ }^{1}$ and \\ Lenka Kubicova ${ }^{1}$ \\ 1 Division of Molecular Systems Biology, Department of Ecogenomics and Systems Biology, \\ Faculty of Life Sciences, University of Vienna, Althanstrasse 14, A-1090 Vienna, Austria; \\ gert.bachmann@univie.ac.at (G.B.); wolfram.weckwerth@univie.ac.at (W.W.); \\ lenka.kubicova@univie.ac.at (L.K.) \\ 2 Department of Plant Biochemistry, Albrecht-von-Haller Institut, Georg-August-Universität Göttingen, \\ Justus-von-Liebig-Weg 11, D-37077 Göttingen, Germany; franz.hadacek@biologie.uni-goettingen.de \\ * Correspondence: vladimir.chobot@univie.ac.at; Tel.: +43-1-4277-76551
}

Received: 29 October 2018; Accepted: 5 December 2018; Published: 7 December 2018

check for updates

\begin{abstract}
Background: The alkaloid 8-hydroxyquinoline (8HQ) is well-known for various biological activities, including antioxidant effects and especially for the formation of coordination complexes with various transition metals, such as iron, amongst others. Therefore, $8 \mathrm{HQ}$ was extensively explored as a promising antineurodegenerative agent. However, other authors noted pro-oxidant effects of $8 \mathrm{HQ}$. Here, we explore the pro- and antioxidant properties of $8 \mathrm{HQ}$, especially in context of coordination complexes with iron (II) and iron (III). Methods: Nano-electrospray-mass spectrometry, differential pulse voltammetry, deoxyribose degradation, iron (II) autoxidation, and brine shrimp mortality assays were used. Results: $8 \mathrm{HQ}$ formed a complex mixture of coordination complexes with iron (II) and iron (III). Furthermore, $8 \mathrm{HQ}$ showed antioxidant effects but no pro-oxidant ones. In the brine shrimp mortality assay, $8 \mathrm{HQ}$ demonstrated toxicity that decreased in the presence of iron (III). Conclusions: $8 \mathrm{HQ}$ is a potent antioxidant whose effects depend not only on the formation of the coordination complexes with iron ions, but surely on the scavenging activities due to the redox properties of the 8-hydroxyl group. No pro-oxidant effects were observed in the set of the used assays.
\end{abstract}

Keywords: Alzheimer's; Fenton reaction; hydroxyl radical; iron chelates; reactive oxygen species

\section{Introduction}

8-Hydroxyquinoline (oxine, 8-quinolinol, $8 \mathrm{HQ}$ ) is an alkaloid with a rather simple chemical structure and occurs in plants of families Asteraceae [1] and Euphorbiaceae [2]. Previous studies revealed a very large spectrum of various biological activities, such as phytotoxic $[1,3]$, antibacterial $[4,5]$, antifungal [6], and insecticidal [2] activities for 8HQ and structurally related compounds. In recent decades, however, its potential as a cure for some neurodegenerative diseases such as Alzheimer's and Parkinson's diseases raised attention $[7,8]$. Beneficial effects in this context have been attributed to the antioxidant properties of $8 \mathrm{HQ}[9]$.

The curative effects of $8 \mathrm{HQ}$ depend primarily on direct scavenging and also on its ability to form coordination complexes with transition metals such as iron [10]. These metals can accumulate in the brain tissue under pathological conditions, and can accelerate tissue destruction by catalyzing the formation of cytotoxic reactive oxygen species (ROS), especially hydroxyl radicals [11].

The antioxidant activities of $8 \mathrm{HQ}$ have been extensively investigated for a long time. However, the different explorations procured contradictory results in terms of the pro- and antioxidant properties 
of $8 \mathrm{HQ}[8,10,12]$. Several authors reported ROS generation and cytotoxicity as a consequence of pro-oxidant effects of $\mathrm{Fe}-8 \mathrm{HQ}$ coordination complexes in vitro [12,13] as well as in cell culture [14] experiments. In contrast, other authors suggested that the antioxidant and beneficial effects of $8 \mathrm{HQ}$ and its derivatives in neurodegenerative or other diseases associated with accumulation of "poorly liganded" iron are connected primarily with coordination complex formation [9,11,15]. Especially, Kayyali et al. characterized $8 \mathrm{HQ}$ as a potent iron (III) complexation agent but poor direct ROS scavenger. However, in other experimental arrangements, $8 \mathrm{HQ}$ was proved as an effective direct ROS scavenger [10].

Furthermore, although $8 \mathrm{HQ}$ is used in analytical chemistry for its capability of forming coordination complexes with transition metals [16], the composition of $\mathrm{Fe}-8 \mathrm{HQ}$ coordination complexes in situ was not fully described. Therefore, we explored the coordination complex formation ability of 8-hydroxyquinoline with iron, their pro- and antioxidant properties, and their toxic effects.

For this purpose, we used nano-ESI-MS and a set of well-established assays: deoxyribose degradation [17], metal autoxidation [18], and brine shrimp (Artemia salina L.) mortality [19,20]. The deoxyribose degradation assays explore the ability of the tested substances to affect hydroxyl radical production by the transition metal-catalyzed Fenton reaction. The metal autoxidation assay assesses the efficiency of the tested compound to influence the metal redox properties in terms of molecular oxygen reduction to ROS. The toxicity of $8 \mathrm{HQ}$ and its coordination complexes with iron was studied by examining its effects on brine shrimp mortality-an assay that is commonly used for screening biological activities [20].

\section{Results}

\subsection{Mass Spectrometry}

The MS spectra proved that $8 \mathrm{HQ}$ formed coordination complexes with both valence forms of iron ions: iron (II) and iron (III) (Figure 1). The isotopic pattern of detected complexes corresponded to the characteristic isotopic pattern of iron $\left({ }^{54} \mathrm{Fe} 5.8 \%,{ }^{56} \mathrm{Fe} 91.7 \%,{ }^{57} \mathrm{Fe} 2.2 \%\right.$, and ${ }^{58} \mathrm{Fe} 0.3 \%$ ). Figure 1 and Table 1 present the assumed compositions and $m / z$ values of prominent coordination complexes of the ${ }^{56} \mathrm{Fe}$ isotope. The figure and the table point out results of the analyzed solutions in which the molar ratio of metal to ligand was adjusted to 1:2. In solutions with other metal-to-ligand ratios, only the intensity but not the $m / z$ values significantly differed.

Table 1. The main signals of ${ }^{56} \mathrm{Fe}-8 \mathrm{HQ}$ (L) coordination complexes in the solutions analyzed by nano-ESI-MS; a positive ionization mode.

\begin{tabular}{|c|c|c|c|c|c|c|}
\hline \multirow[b]{2}{*}{ Composition } & \multirow[b]{2}{*}{ Formula } & \multirow[b]{2}{*}{$\begin{array}{c}m / z \\
\text { Calculated }\end{array}$} & \multicolumn{2}{|c|}{$\mathrm{L}: \mathrm{Fe}^{\mathrm{II}} 2: 1$} & \multicolumn{2}{|c|}{$\mathrm{L}: \mathrm{Fe}^{\mathrm{III}}$ 2:1 } \\
\hline & & & $m / z$ Found & $\Delta(\mathrm{ppm})$ & $m / z$ Found & $\Delta(\mathrm{ppm})$ \\
\hline$[\mathrm{L}+\mathrm{H}]^{+}$ & {$\left[\mathrm{C}_{9} \mathrm{H}_{8} \mathrm{NO}^{+}\right.$} & 146.0600 & 146.0594 & -0.59 & 146.0593 & -0.71 \\
\hline$[\mathrm{L}+\mathrm{Na}]^{+}$ & {$\left[\mathrm{C}_{9} \mathrm{H}_{7} \mathrm{NNaO}\right]^{+}$} & 168.0420 & 168.0413 & -0.71 & 168.0412 & -0.82 \\
\hline$\left[\mathrm{L}+\mathrm{Fe}^{\mathrm{II}}+\mathrm{MeOH}-\mathrm{H}\right]^{+}$ & {$\left[\mathrm{C}_{10} \mathrm{H}_{10} \mathrm{FeNO}_{2}\right]^{+}$} & 232.0055 & 232.0044 & -4.76 & - & - \\
\hline$\left[3 \mathrm{~L}+\mathrm{Fe}^{\mathrm{II}}+\mathrm{Fe}^{\mathrm{III}}-3 \mathrm{H}\right]^{2+}$ & {$\left[\mathrm{C}_{27} \mathrm{H}_{18} \mathrm{Fe}_{2} \mathrm{~N}_{3} \mathrm{O}_{3}\right]^{2+}$} & 272.0018 & 272.0005 & -4.86 & - & - \\
\hline$\left[2 \mathrm{~L}+\mathrm{Fe}^{\mathrm{III}}-2 \mathrm{H}\right]^{+}$ & {$\left[\mathrm{C}_{18} \mathrm{H}_{12} \mathrm{FeN}_{2} \mathrm{O}_{2}\right]^{+}$} & 344.0243 & 344.0223 & -5.87 & 344.0219 & -6.98 \\
\hline$\left[3 \mathrm{~L}+\mathrm{Fe}^{\mathrm{III}}-2 \mathrm{H}\right]^{+}$ & {$\left[\mathrm{C}_{27} \mathrm{H}_{19} \mathrm{FeN}_{3} \mathrm{O}_{3}\right]^{+}$} & 489.0770 & 489.0743 & -5.54 & 489.0740 & -6.29 \\
\hline$\left[3 \mathrm{~L}+\mathrm{Fe}^{\mathrm{III}}+\mathrm{Na}-3 \mathrm{H}\right]^{+}$ & {$\left[\mathrm{C}_{27} \mathrm{H}_{18} \mathrm{FeN}_{3} \mathrm{NaO}_{3}\right]^{+}$} & 511.0590 & 511.0559 & -5.93 & 511.0557 & -6.44 \\
\hline$\left[4 \mathrm{~L}+\mathrm{Fe}^{\mathrm{II}}+\mathrm{Fe}^{\mathrm{III}}-4 \mathrm{H}\right]^{+}$ & {$\left[\mathrm{C}_{36} \mathrm{H}_{24} \mathrm{Fe}_{2} \mathrm{~N}_{4} \mathrm{O}_{4}\right]^{+}$} & 688.0491 & 688.0454 & -5.30 & 688.0451 & -5.84 \\
\hline$\left[5 \mathrm{~L}+2 \mathrm{Fe}^{\mathrm{III}}-5 \mathrm{H}\right]^{+}$ & {$\left[\mathrm{C}_{45} \mathrm{H}_{30} \mathrm{Fe}_{2} \mathrm{~N}_{5} \mathrm{O}_{5}\right]^{+}$} & 832.0940 & 832.0897 & -5.16 & 832.0893 & -5.74 \\
\hline$\left[6 \mathrm{~L}+2 \mathrm{Fe}^{\mathrm{III}}+\mathrm{Na}-6 \mathrm{H}\right]^{+}$ & {$\left[\mathrm{C}_{54} \mathrm{H}_{36} \mathrm{Fe}_{2} \mathrm{~N}_{6} \mathrm{NaO}_{6}\right]^{+}$} & 999.1287 & 999.1239 & -4.86 & 999.1228 & -5.99 \\
\hline
\end{tabular}




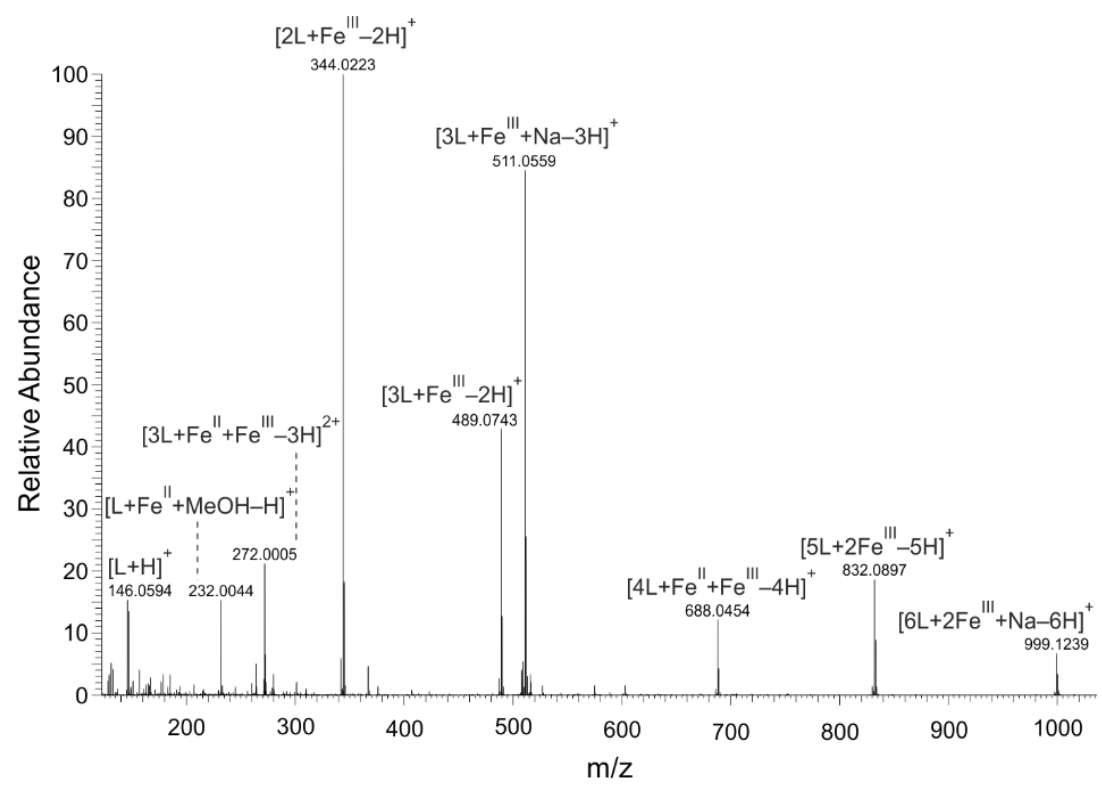

(a)

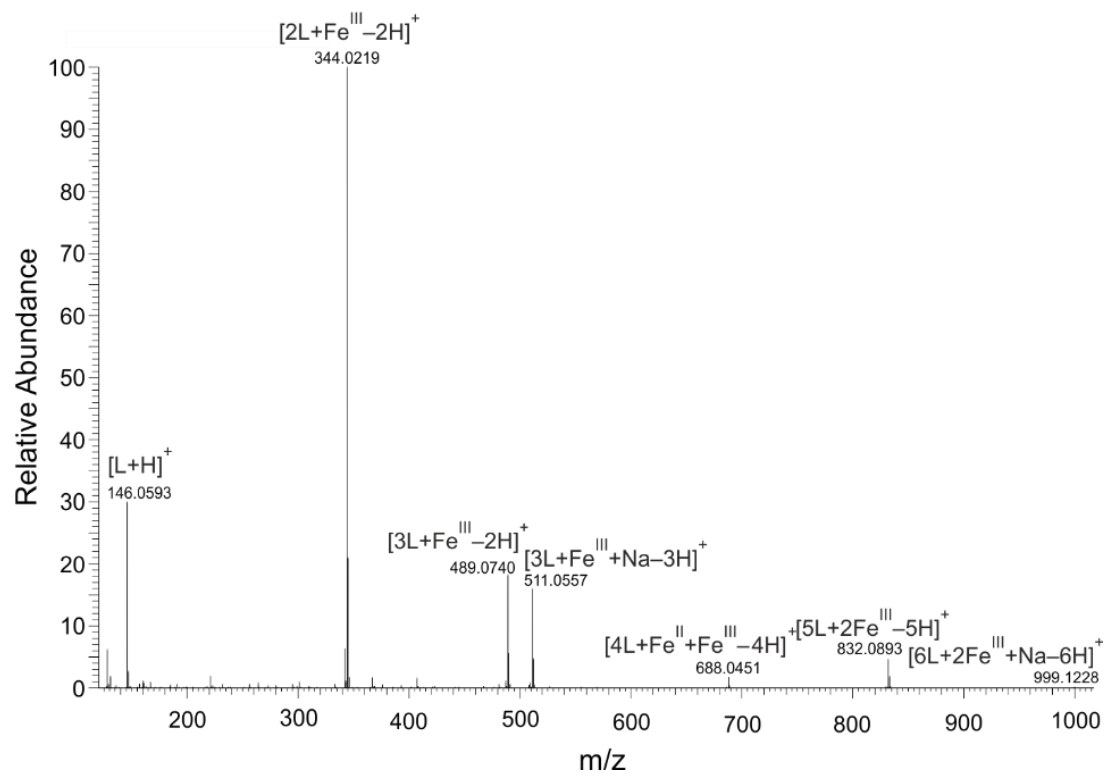

(b)

Figure 1. Mass spectra of $\mathrm{Fe}-8 \mathrm{HQ}(\mathrm{L})$ coordination complexes detected in solutions by nano-ESI-MS (nano-electrospray-mass spectrometry); positive ionization mode. The solutions were prepared by mixing of 8-hydroxyquinoline (8HQ) solution with (a) $\mathrm{Fe}^{\mathrm{II}}$ or (b) $\mathrm{Fe}^{\mathrm{III}}$ solutions in molar ratio of metal to ligand of 1:2.

\subsection{Differential Pulse Voltammetry}

The differential pulse voltammogram of $8 \mathrm{HQ}$ showed one prominent peak at $482 \mathrm{mV}$ (Figure 2). The shape of this peak indicated a complicated electrochemical oxidation process of the 8-hydroxyl group that is probably followed by further chemical reactions as proposed by Stevic et al. [21]. After the addition of iron (II) solution, the current of this peak decreased (Figure 2). Furthermore, its potential shifted to the anodic direction $(518 \mathrm{mV})$. Moreover, two other peaks at 108 and $913 \mathrm{mV}$ were visible on the voltammogram. By contrast, iron (II) solution showed only one broad peak at $-74 \mathrm{mV}$ of low current. 


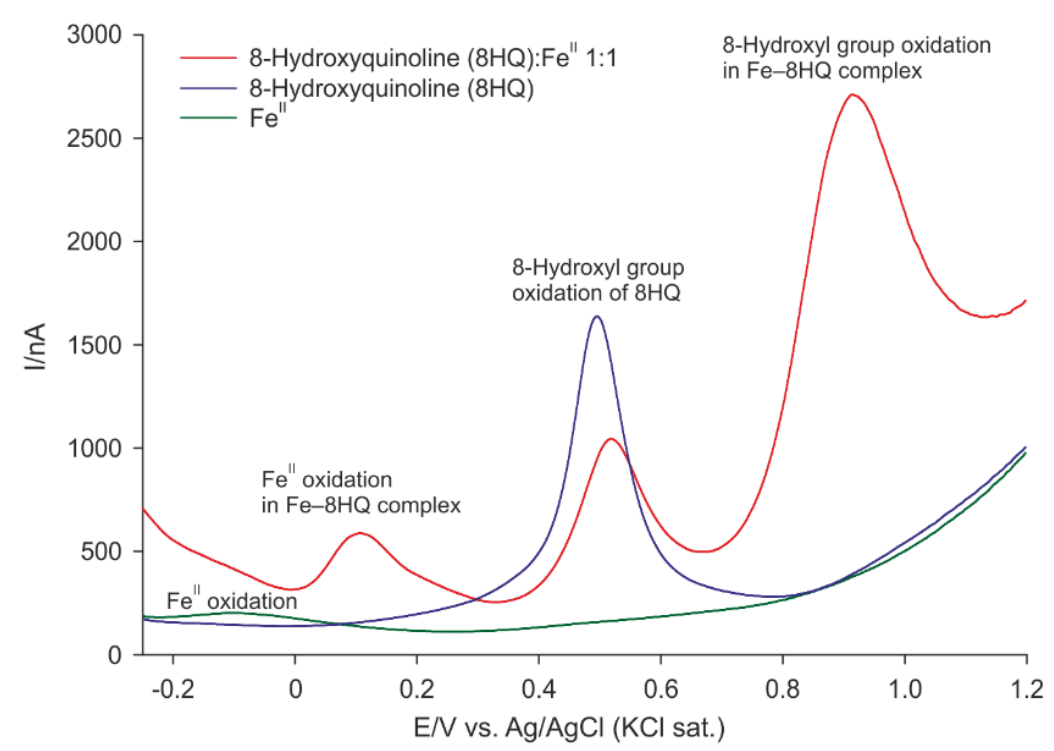

Figure 2. Differential pulse voltammograms of a $1: 1 \mathrm{Fe}^{\mathrm{II}}-8 \mathrm{HQ}$ mixture, $\mathrm{Fe}^{\mathrm{II}}$, and $8 \mathrm{HQ}$ solutions.

\subsection{Deoxyribose Degradation Assay}

This assay explores the capability of various substances to inhibit the degradation of 2-deoxyribose by hydroxyl radicals, which are generated by the iron-catalyzed Fenton reaction [17]. Figure 3a (Table S1) shows that the antioxidant activity of $8 \mathrm{HQ}$ depended strongly on the $\mathrm{pH}$ of the reaction solution. $8 \mathrm{HQ}$ was a more efficient antioxidant at $\mathrm{pH} 7.4$ than at $\mathrm{pH}$ 6.0. Nevertheless, $8 \mathrm{HQ}$ demonstrated an apparent ability to inhibit the oxidative degradation of 2-deoxyribose by hydroxyl radical.

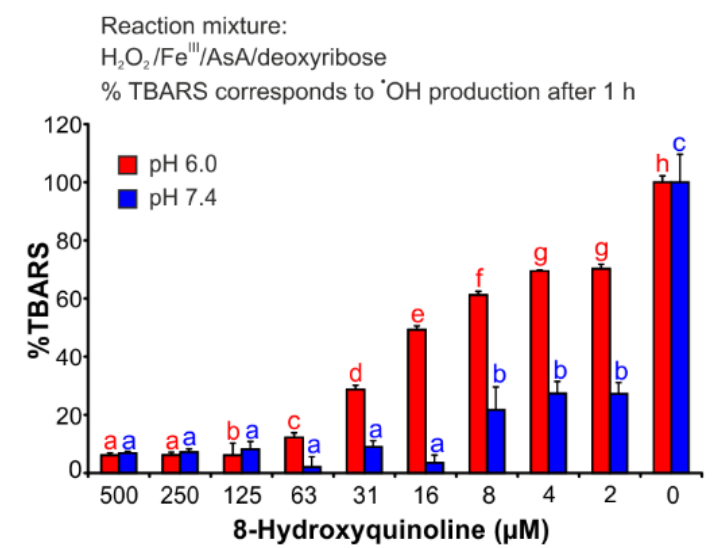

(a)

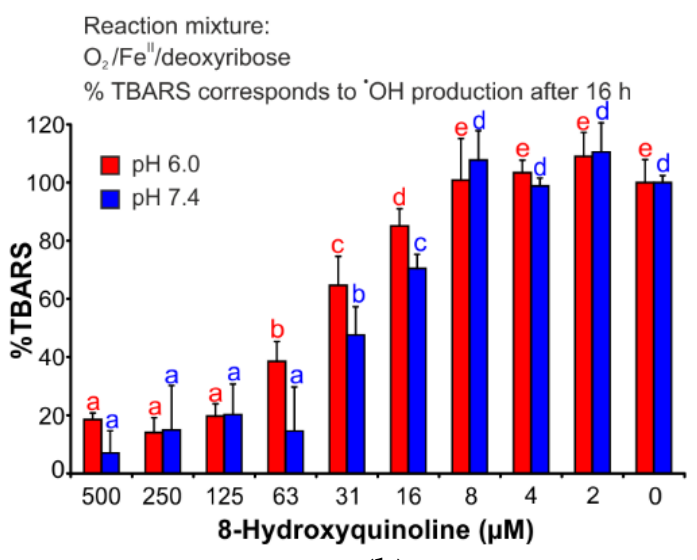

(b)

Figure 3. Antioxidant effects of $8 \mathrm{HQ}$ in (a) deoxyribose degradation assay and (b) iron (II) autoxidation assay. The bars are the means of three replications ( \pm S.D.). Letters $a-h$ in subfigure (a) and a-e in subfigure (b) indicate significance levels (95\% Duncan's post hoc test). AsA: ascorbic acid; TBARS: thiobarbituric acid reactive species; S.D.: standard deviation.

\subsection{Iron (II) Autoxidation Assay}

This assay offers the possibility of investigating the effects of various substances on ROS production that is specifically caused by the autoxidation of iron (II) [18]. 8HQ efficiently affected the reactions that decompose 2-deoxyribose (Figure 3b, Table S2). However, in this assay, the effect was less dependent on $\mathrm{pH}$ compared to the deoxyribose degradation assay. Nonetheless, the results 
showed that $8 \mathrm{HQ}$ is an efficient antioxidant and it was able to protect 2-deoxyribose against ROS attacks induced by iron (II) autoxidation.

\subsection{Brine Shrimp Mortality Assay}

The larvae of the invertebrate crustacean Artemia salina L. were very sensitive to $8 \mathrm{HQ}$ (Figure 4, Table S3). A concentration of $125 \mu \mathrm{M}$ caused nearly $100 \%$ mortality. Contrary, when $8 \mathrm{HQ}$ was a ligand in iron coordination complexes, the mortality decreased dramatically. The observed toxicity values matched those of the control assay and of the iron (III) chloride solution.

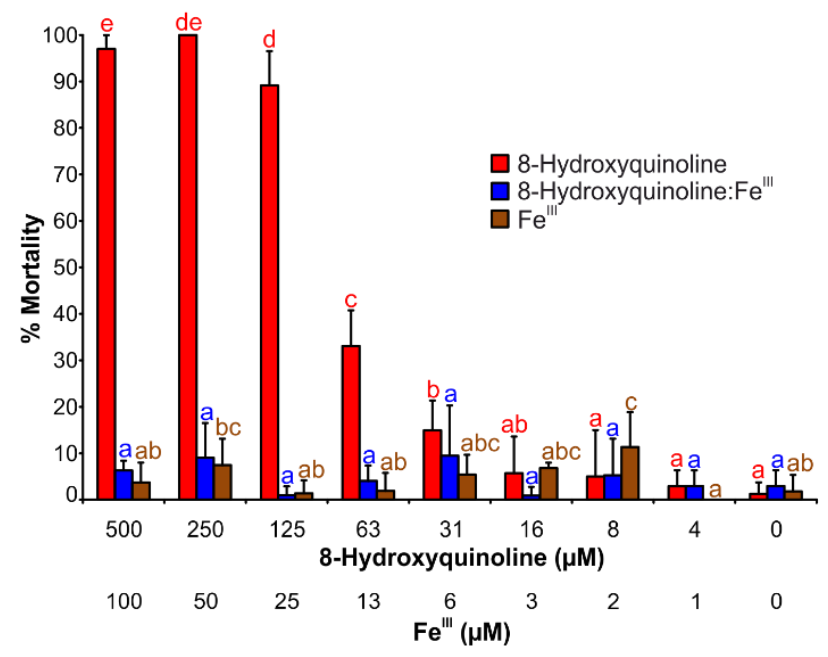

Figure 4. Brine shrimp (Artemia salina L.) mortality caused by $8 \mathrm{HQ}$ in free form and as $\mathrm{Fe}^{\mathrm{III}}-8 \mathrm{HQ}$ complexes. The upper scale designates the concentration of $8 \mathrm{HQ}$, the lower one the concentration of iron (III) in the tested solution. The bars represent means of eight replicates ( \pm S.D.). The different significance levels were determined by Duncan's post hoc test (95\%) and are indicated by the letters a-e above the error bars.

\section{Discussion}

Mass spectrometry showed that $8 \mathrm{HQ}$ can form various coordination complexes in situ with iron (II) and iron (III). In addition to one iron coordination complexes, also two iron coordination complexes were present in the solution. In these binuclear coordination complexes of $8 \mathrm{HQ}$, the iron atoms were present either in the same or in different oxidation states. However, mass spectrometry detected mainly coordination complexes of $8 \mathrm{HQ}$ with iron (III) because the corresponding coordination complexes with iron (II) were electro-neutral. Thus, they were not detectable by mass spectrometry. Nevertheless, the ability of $8 \mathrm{HQ}$ to easily form coordination complexes with metals is a major reason for the wide use of $8 \mathrm{HQ}$ in analytical chemistry for the spectrophotometric determination of various metals [16].

The results of differential pulse voltammetry (DPV) agreed with those obtained by mass spectrometry. Compared to free iron ions, the redox potential of iron in the coordination complexes with $8 \mathrm{HQ}$ shifted to more positive values. However, due to the formation of various different complexes in the analyzed solutions, the iron oxidation peak showed a very broad and asymmetric form. Furthermore, the signal of 8-hydroxyl group of Fe-8HQ coordination complexes appeared at more positive potentials in comparison with free $8 \mathrm{HQ}$. Nevertheless, the voltammograms proved that $8 \mathrm{HQ}$ antioxidant properties depend not only on quenching iron's catalysis of the Fenton reaction but also on the redox activity of the 8-hydroxyl group.

The DPV results corresponded well with those obtained in the deoxyribose degradation and iron (II) autoxidation assays. In both, $8 \mathrm{HQ}$ was proved as a potent antioxidant. Especially, in the deoxyribose degradation assay, $8 \mathrm{HQ}$ showed stronger antioxidant activities than the flavonoids catechin and quercetin $[17,22]$. Furthermore, $8 \mathrm{HQ}$ was more effective in the iron (II) autoxidation assay 
than a number of well-known phenolic antioxidants such as the flavonoids quercetin and rutin and the phenolic acids chlorogenic, caffeic, and protocatechuic acid, all of which had been assayed in closely similar arrangements [18]. Contrary to quercetin, at $\mathrm{pH} 7.4,8 \mathrm{HQ}$ showed no pro-oxidant effects in the iron (II) autoxidation assay. However, at $\mathrm{pH} 6.0$ (i.e., the $\mathrm{pH}$ of inflamed tissue), antioxidant effects of $8 \mathrm{HQ}$ are still possible [18]. The antioxidant ability of $8 \mathrm{HQ}$ probably varies due to an extension of the aromatic system that can stabilize semi-quinone radical [23] and protonization of the heterocyclic nitrogen atom and 8-hydroxyl group.

The results of brine shrimp toxicity assay agreed with the results of other published bioassays of $8 \mathrm{HQ}$, especially with those carried out with various microorganisms [10]. 8HQ is well-known as an antimicrobial agent and its derivatives are currently used in medicine, predominately in dermatology $[7,8,24]$. In the presence of iron ions [10], the antimicrobial activity of $8 \mathrm{HQ}$ decreased.

Brine shrimp larvae are often used in ecotoxicology for testing environmental pollutants [20]. However, these larvae are also sensitive to various ROS $[25,26]$ and thus represent good sensors for ROS development. Therefore, we performed brine shrimp mortality assays to explore the possible pro-oxidant effects of the $8 \mathrm{HQ}$ complexes with iron as possible ROS producers. Only the free $8 \mathrm{HQ}$ caused apparent toxicity. By contrast, the toxicity disappeared in the presence of iron ions in the tested solution. A ratio of 5:1 of $8 \mathrm{HQ}$ to iron (III) was chosen to prevent complex formation of iron with phosphate anions of the buffer.

The $\mathrm{Fe}-8 \mathrm{HQ}$ coordination complexes can diffuse easily through cellular membranes due to the increased liposolubility of the coordination complexes. However, 8HQ cannot serve as a good siderophore because of the high stability of its coordination complexes with iron [27]. The long-term iron deficiency caused by $8 \mathrm{HQ}$ increased ROS levels and a non-autolytic programmed cell death in plants [27]. In contrast, the brine shrimp mortality assay detected no toxicity of Fe $\mathrm{F}^{\mathrm{III}}-8 \mathrm{HQ}$ coordination complexes. A longer duration of the assay probably would have produced such results.

Our results provided support for the rational background of $8 \mathrm{HQ}$ use as a promising agent for neurodegenerative disease treatment, such as Alzheimer's or Parkinson's disease. These diseases are well-known to be accelerated by the accumulation of "poorly liganded" iron in the brain tissue that results in increased ROS production [11], especially in the case of damaged blood-brain barrier (BBB) [28]. Our investigation showed that $8 \mathrm{HQ}$ is a potent coordination complex-forming agent on the one hand, and an excellent ROS scavenger on the other. Both of these $8 \mathrm{HQ}$ properties may contribute to inhibition of the mentioned neurodegenerative processes.

\section{Materials and Methods}

\subsection{Chemicals}

The used chemicals were purchased from Sigma-Aldrich (Schnelldorf, Germany). Water was of Milli-Q quality (Milli-Q Advantage A10 System, Milllipore SAS, Molsheim, France).

\subsection{Mass Spectrometry}

Direct infusion nano-electrospray ionization mass spectrometry was carried out in positive ionization mode on a Thermo Electron LTQ-Orbitrap XL mass spectrometer equipped with a nano electrospray ion source (ThermoFisher Scientific, Bremen, Germany) and operated under Xcalibur software 2.2 (ThermoFisher Scientific, Bremen, Germany) as described by Kubicova et al. [29]. Theoretical masses and characteristic iron isotopic patterns were calculated by Xcalibur software 2.2 (ThermoFisher Scientific, Bremen, Germany).

\subsection{Differential Pulse Voltammetry}

The detailed procedures are described elsewhere [30]. For records of differential pulse voltammograms, a three-electrode system, $\mu$ Autolab PGSTAT type III (EcoChemie Inc., Utrecht, The Netherlands), was used. A glassy carbon electrode ( $3 \mathrm{~mm}$ of diameter) served as a working 
electrode, a platinum wire as a counter electrode, and $\mathrm{Ag} / \mathrm{AgCl}$ (saturated aqueous solution of $\mathrm{KCl}$ ) as a reference electrode.

The electrochemical experiments were adjusted as follows: The effective scan rate of the voltammetry was $21 \mathrm{mV} / \mathrm{s}$, modulation time was $0.05 \mathrm{~s}$, modulation amplitude was $25 \mathrm{mV}$, and the scan potential was from -0.250 to $+1.200 \mathrm{~V}$. The solution of supporting electrolyte was degassed buffer ( $0.1 \mathrm{M}$ phosphate buffer $\mathrm{pH} 7.4$; buffer ionic strength $1 \mathrm{M}$, adjusted by $\mathrm{K}_{2} \mathrm{SO}_{4}$ ). The voltammograms were recorded for various metal-to-ligand ratios.

\subsection{Deoxyribose Degradation Assay}

The "site-specific" deoxyribose degradation assay (reaction mixture $\mathrm{H}_{2} \mathrm{O}_{2} / \mathrm{FeCl}_{3}$ /ascorbic acid) was performed as described in detail elsewhere [17]. The used buffers were aqueous solutions of $\mathrm{KH}_{2} \mathrm{PO}_{4} / \mathrm{KOH}(30 \mathrm{mM}, \mathrm{pH} 7.4)$ and $\mathrm{KH}_{2} \mathrm{PO}_{4} / \mathrm{H}_{3} \mathrm{PO}_{4}(30 \mathrm{mM}, \mathrm{pH}$ 6.0).

\subsection{Iron (II) Autoxidation Assay}

The procedures and reaction mechanisms were published by Chobot et al. [18]. The aqueous solutions of $\mathrm{KH}_{2} \mathrm{PO}_{4} / \mathrm{KOH}\left(30 \mathrm{mM}\right.$, pH 7.4) and $\mathrm{KH}_{2} \mathrm{PO}_{4} / \mathrm{H}_{3} \mathrm{PO}_{4}(30 \mathrm{mM}$, pH 6.0) were used as buffers.

\subsection{Brine Shrimp Mortality Assay}

For each experiment, $0.5 \mathrm{~g}$ of Artemia salina cysts were hatched in $25 \mathrm{~mL}$ of buffered saline aqueous solution ( $\mathrm{pH}$ 7.4). Since larvae (nauplii) are extremely sensitive to any quick $\mathrm{pH}$ change of the cultivation solution, the experiment was carried out in aqueous solution of buffered saline to stabilize pH (g per $1 \mathrm{~L}: 8.0 \mathrm{NaCl}, 0.2 \mathrm{KH}_{2} \mathrm{PO}_{4}, 1.15 \mathrm{Na}_{2} \mathrm{HPO}_{4}, 0.2 \mathrm{KCl}$ ). For hatching, illumination was performed with a $60 \mathrm{~W}$ lamp from a distance of $40 \mathrm{~cm}$ for $1 \mathrm{~h}$. The hatched larvae were transferred to an incubator $\left( \pm 25.0^{\circ} \mathrm{C}\right)$.

One hundred $\mu \mathrm{L}$ of the stock solution was serially diluted in 96-well microplates, and $50 \mu \mathrm{L}$ of suspension of 24 -h old larvae (6-30 larvae) were added. The stock solution was prepared by mixing a buffered solution of the tested compound $(500 \mu \mathrm{M})$ with aqueous solution $(100 \mu \mathrm{M})$ of iron (III) chloride $(1: 1 \mathrm{v} / \mathrm{v})$. The ligand-to-metal ratio was kept at 5:1 to decrease competition of other ligands present in the solution, especially phosphates. The tested iron ions were added in the assay system in their most stable valent state $\left(\mathrm{Fe}^{\mathrm{III}}\right)$.

After $24 \mathrm{~h}$, the wells were scored visually for dead animals (larvae without any movement for at least $10 \mathrm{~s}$ ) by using a stereomicroscope. Fifty $\mu \mathrm{L}$ of $0.1 \mathrm{M} \mathrm{HCl}$ were used to kill all animals. In a second scoring survey, all animals were counted for each well to calculate the number of surviving larvae for each concentration tested, as required for a quantal biological assay. The negative control was the buffered saline solution without the test compound. One set of experiments was performed with $8 \mathrm{HQ}$ without the addition of iron (III) chloride ions and another experimental set was carried out in solutions of iron (III) chloride without the addition of 8HQ.

Supplementary Materials: The following are available online at http:/ / www.mdpi.com/1422-0067/19/12/3917/s1.

Author Contributions: Conceptualization, V.C. and L.K.; Methodology, V.C. and L.K.; Formal Analysis, V.C., F.H., G.B., and L.K.; Investigation, V.C. and L.K.; Resources, W.W.; Data Curation, V.C. and L.K.; Writing-Original Draft Preparation, V.C. and F.H.; Writing-Review \& Editing, V.C., F.H., G.B., L.K., and W.W.; Visualization, V.C. and L.K.; Project Administration, V.C., G.B., and L.K.; Funding Acquisition, V.C., F.H., and W.W.

Funding: This research was funded by the Austrian Science Fund (FWF), grant number P 24630-B21.

Conflicts of Interest: The authors declare no conflict of interest. 


\section{Abbreviations}

$\begin{array}{ll}\text { AsA } & \text { Ascorbic acid } \\ \text { BBB } & \text { Blood-brain barrier } \\ \text { DPV } & \text { Differential pulse voltammetry } \\ \text { 8HQ } & \text { 8-Hydroxyquinoline } \\ \text { L } & \text { Ligand } \\ \text { Nano-ESI-MS } & \text { Nano-electrospray-mass spectrometry } \\ \text { ROS } & \text { Reactive oxygen species } \\ \text { S.D. } & \text { Standard deviation } \\ \text { TBARS } & \text { Thiobarbituric acid reactive species }\end{array}$

\section{References}

1. Tharayil, N.; Bhowmik, P.; Alpert, P.; Walker, E.; Amarasiriwardena, D.; Xing, B. Dual purpose secondary compounds: Phytotoxin of Centaurea diffusa also facilitates nutrient uptake. New Phytol. 2009, 181, 424-434. [CrossRef]

2. Lee, C.H.; Jeon, J.H.; Lee, S.G.; Lee, H.S. Insecticidal properties of Euphorbiaceae: Sebastiania corniculataderived 8-hydroxyquinoline and its derivatives against three plant hopper species (Hemiptera: Delphacidae). J. Korean Soc. Appl. Biol. Chem. 2010, 53, 464-469. [CrossRef]

3. Jampilek, J.; Kralova, K.; Pesko, M.; Kos, J. Ring-substituted 8-hydroxyquinoline-2-carboxanilides as photosystem II inhibitors. Bioorg. Med. Chem. Lett. 2016, 26, 3862-3865. [CrossRef]

4. Novakova, J.; Dzunkova, M.; Musilova, S.; Vlkova, E.; Kokoska, L.; Moya, A.; D’Auria, G. Selective growth-inhibitory effect of 8-hydroxyquinoline towards Clostridium difficile and Bifidobacterium longum subsp longum in co-culture analysed by flow cytometry. J. Med. Microbiol. 2014, 63, 1663-1669. [CrossRef]

5. Skrivanova, E.; Van Immerseel, F.; Hovorkova, P.; Kokoska, L. In vitro selective growth-Inhibitory effect of 8-hydroxyquinoline on Clostridium perfringens versus Bifidobacteria in a medium containing chicken ileal digesta. PLoS ONE 2016, 11, e0167638. [CrossRef]

6. Pippi, B.; Reginatto, P.; Machado, G.D.M.; Bergamo, V.Z.; Dalla Lana, D.F.; Teixeira, M.L.; Franco, L.L.; Alves, R.J.; Andrade, S.F.; Fuentefria, A.M. Evaluation of 8-hydroxyquinoline derivatives as hits for antifungal drug design. Med. Mycol. 2017, 55, 763-773. [CrossRef]

7. Oliveri, V.; Vecchio, G. 8-Hydroxyquinolines in medicinal chemistry: A structural perspective. Eur. J. Med. Chem. 2016, 120, 252-274. [CrossRef]

8. Prachayasittikul, V.; Prachayasittikul, S.; Ruchirawat, S. 8-Hydroxyquinolines: A review of their metal chelating properties and medicinal applications. Drug Des. Devel. Ther. 2013, 7, 1157-1178. [CrossRef]

9. Kell, D.B. Iron behaving badly: Inappropriate iron chelation as a major contributor to the aetiology of vascular and other progressive inflammatory and degenerative diseases. BMC Med. Genom. 2009, 2, 2. [CrossRef]

10. Chobot, V.; Drage, S.; Hadacek, F. Redox properties of 8-quinolinol and implications for its mode of action. Nat. Prod. Commun. 2011, 6, 597-602.

11. Kell, D.B. Towards a unifying, systems biology understanding of large-scale cellular death and destruction caused by poorly liganded iron: Parkinson's, Huntington's, Alzheimer's, prions, bactericides, chemical toxicology and others as examples. Arch. Toxicol. 2010, 84, 825-889. [CrossRef]

12. Murakami, K.; Haneda, M.; Yoshino, M. Prooxidant action of xanthurenic acid and quinoline compounds: Role of transition metals in the generation of reactive oxygen species and enhanced formation of 8-hydroxy-2 '-deoxyguanosine in DNA. Biometals 2006, 19, 429-435. [CrossRef]

13. Leanderson, P.; Tagesson, C. Iron bound to the lipophilic iron chelator, 8-hydroxyquinoline, causes DNA strand breakage in cultured lung cells. Carcinogenesis 1996, 17, 545-550. [CrossRef]

14. Fang, S.L.; Yu, X.N.; Ding, H.X.; Han, J.A.; Feng, J. Effects of intracellular iron overload on cell death and identification of potent cell death inhibitors. Biochem. Biophys. Res. Commun. 2018, 503, 297-303. [CrossRef]

15. Kayyali, R.; Pannala, A.S.; Khodr, H.; Hider, R.C. Comparative radical scavenging ability of bidentate iron(III) chelators. Biochem. Pharmacol. 1998, 55, 1327-1332. [CrossRef]

16. Lange, B. Kolorimetrische Analyse mit Besonderer Besichtigung der Lichtelektrischen Kolorimetrie, 1st ed.; Verlag Chemie, G.M.B.H: Berlin, Germany, 1941. 
17. Chobot, V. Simultaneous detection of pro- and antioxidative effects in the variants of the deoxyribose degradation assay. J. Agric. Food Chem. 2010, 58, 2088-2094. [CrossRef]

18. Chobot, V.; Hadacek, F.; Kubicova, L. Effects of selected dietary secondary metabolites on reactive oxygen species production caused by iron(II) autoxidation. Molecules 2014, 19, 20023-20033. [CrossRef]

19. Kubicova, L.; Sustr, M.; Kral'ova, K.; Chobot, V.; Vytlacilova, J.; Jahodar, L.; Vuorela, P.; Machacek, M.; Kaustova, J. Synthesis and biological evaluation of quinazoline-4-thiones. Molecules 2003, 8, 756-769. [CrossRef]

20. Nunes, B.S.; Carvalho, F.D.; Guilhermino, L.M.; Van Stappen, G. Use of the genus Artemia in ecotoxicity testing. Environ. Pollut. 2006, 144, 453-462. [CrossRef]

21. Stevic, M.C.; Ignjatovic, L.M.; Ciric-Marjanovic, G.; Stanisic, S.M.; Stankovic, D.M.; Zima, J. Voltammetric behaviour and determination of 8-hydroxyquinoline using a glassy carbon paste electrode and the theoretical study of its electrochemical oxidation mechanism. Int. J. Electrochem. Sci. 2011, 6, 2509-2525.

22. Chobot, V.; Huber, C.; Trettenhahn, G.; Hadacek, F. (+/-)-Catechin: Chemical weapon, antioxidant, or stress regulator? J. Chem. Ecol. 2009, 35, 980-996. [CrossRef]

23. Rice-Evans, C.A.; Miller, N.J.; Paganga, G. Structure-antioxidant activity relationships of flavonoids and phenolic acids. Free Radical Biol. Med. 1996, 20, 933-956. [CrossRef]

24. Bareggi, S.R.; Cornelli, U. Clioquinol: Review of its mechanisms of action and clinical uses in neurodegenerative disorders. CNS Neurosci. Ther. 2012, 18, 41-46. [CrossRef]

25. Matthews, R.S. Artemia salina as a test organism for measuring superoxide-mediated toxicity. Free Radical Biol. Med. 1995, 18, 919-922. [CrossRef]

26. Chobot, V.; Vytlacilova, J.; Kubicova, L.; Opletal, L.; Jahodaar, L.; Laakso, I.; Vuorela, P. Phototoxic activity of a thiophene polyacetylene from Leuzea carthamoides. Fitoterapia 2006, 77, 194-198. [CrossRef]

27. Tewari, R.K.; Bachmann, G.; Hadacek, F. Iron in complex with the alleged phytosiderophore 8-hydroxyquinoline induces functional iron deficiency and non-autolytic programmed cell death in rapeseed plants. Environ. Exp. Bot. 2015, 109, 151-160. [CrossRef]

28. Montagne, A.; Zhao, Z.; Zlokovic, B.V. Alzheimer's disease: A matter of blood-brain barrier dysfunction? J. Exp. Med. 2017, 214, 3151-3169. [CrossRef]

29. Kubicova, L.; Hadacek, F.; Weckwerth, W.; Chobot, V. Effects of endogenous neurotoxin quinolinic acid on reactive oxygen species production by Fenton reaction catalyzed by iron or copper. J. Organomet. Chem. 2015, 782, 111-115. [CrossRef]

30. Kubicova, L.; Hadacek, F.; Chobot, V. Quinolinic Acid: Neurotoxin or oxidative stress modulator? Int. J. Mol. Sci. 2013, 14, 21328-21338. [CrossRef]

(C) 2018 by the authors. Licensee MDPI, Basel, Switzerland. This article is an open access article distributed under the terms and conditions of the Creative Commons Attribution (CC BY) license (http:/ / creativecommons.org/licenses/by/4.0/). 